\title{
Perception of oyster-based products by French consumers. The effect of processing and role of social representations
}

\author{
Gervaise Debucquet $^{\mathrm{a}},{\text { Josiane } \text { Cornet }^{\mathrm{b}} \text {, Isabelle Adam }}^{\mathrm{b}}$, Mireille Cardinal ${ }^{\mathrm{b},{ }^{*}}$
}

a Audencia-Nantes, School of Management, PRES-LUNAM, LESMA (Laboratoire de recherche en Stratégie et Marchés des produits Agroalimentaires), 8 route de la Jonelière, BP 31222 , F-44312 Nantes 03, France

${ }^{b}$ Ifremer, Laboratoire Science et Technologie de la Biomasse Marine, F-44311 Nantes 03, France

*: Corresponding author : Mireille Cardinal, email address : Mireille.Cardinal@ifremer.fr

\begin{abstract}
:
The search for new markets in the seafood sector, associated with the question of the continuity of raw oyster consumption over generations can be an opportunity for processors to extend their ranges with oyster-based products. The twofold aim of this study was to evaluate the impact of processing and social representation on perception of oyster-based products by French consumers and to identify the best means of development in order to avoid possible failure in the market. Five products with different degrees of processing (cooked oysters in a half-shell, hot preparation for toast, potted oyster, oyster butter and oyster-based soup) were presented within focus groups and consumer tests, at home and in canteens with the staff of several companies in order to reach consumers with different ages and professional activities. The results showed that social representation had a strong impact and that behaviours were contrasted according to the initial profile of the consumer (traditional raw oyster consumers or non-consumers) and their age distribution (younger and older people). The degree of processing has to be adapted to each segment. It is suggested to develop early exposure to influence the food choices and preferences of the youngest consumers on a long-term basis.
\end{abstract}

\section{Highlights}

- Orientations for the development of oyster-based products on the French market. Social representation has a strong impact on perception of oyster-based products. Eating or not raw oyster modifies consumer behaviour. Two different markets according to consumers' expectations and age distribution. The degree of processing has to be adapted to each segment.

Keywords : Oyster ; Processing ; Consumer perception ; Disgust ; Social representation

\section{Introduction}

Of the European countries that produce oysters, France is the leader with around 113,000 tons (France Agrimer, 2010) and ranks fourth at the world level after China, Japan and Korea. France has the characteristic to sell nearly all its production on the national market. Oysters (Crassostrea gigas) are a traditional product mainly consumed in their live form, and in spite of the producers' efforts to extend the period of consumption, they still remain a seasonal product for the French market, with a peak of consumption between Christmas and New Year's Day (Girard \& Mariojouls, 2003). Therefore, in French food culture, oysters belong to the category of rare and luxury foods. A recent survey on household consumption (Panel Kantar Worldpanel) conducted in 2009 for France Agrimer (2010) showed that only $21 \%$ of households bought oysters at least once a year even though two thirds of the French population consume the product. This study also confirms a certain stability in consumption, as well as the importance of "cultural", "economic" and "demographic" factors in consumers' behaviour, as already observed by Girard and Mariojouls (2003). The consumer profile for fresh oysters is essentially a person over the age of 50, in an upper income bracket, living in the West of France and generally in a household of two people. On the contrary, non-consumers 
of oysters, generally among the youngest, consider that this product is too costly and difficult to open, and the specific characteristics of oysters (live, raw and viscous) play a part in developing a certain aversion to this product. This difference in behaviour between young and senior purchasers may lead to a deficit in the recruitment of "new" consumers, and perhaps ultimately leading to critical questions regarding the future of oyster consumption. How can the continuity of oyster consumption be guaranteed down through the generations? This question highlights the importance of promoting the product with young people, but perhaps also of diversifying the range of oyster-based products. This search for new markets could also be an opportunity for processors to extend their range of seafood products.

However, to find the best ways to develop and to avoid possible failure in the market, it is necessary to take into account as early as possible the psychological barriers related to oyster consumption and to analyse the potential for processed oyster-based products through consumer perception. Understanding consumer reactions to new products is especially interesting in the case of oysters as they are known to cause extremely marked reactions. Many non-consumers are disgusted by oysters because of their appearance and the consumers' unwillingness to consume something alive and viscous. In the literature, "disgust" deals specifically with animal substances versus plant substances because of the moral dimension linked with their ingestion by eaters, as shown by Rozin and Fallon (1987). In other respects, Kolnai (1998) has identified these two physical characteristics, alive and viscous, as the most common and strongest sources of disgust. French consumers naturally ingest raw, live oysters thanks to French culture which allows them to "appropriate" these particular sensory qualities by classifying them in the category of rare, luxury and healthy food. The feelings of disgust are strongly reduced by the fact that when ingesting oysters a lot of other, generally positive, symbols are ingested at the same time. Fischler (1990) showed that food ingestion is not an ordinary action but one that always has a symbolic dimension. 
Thus, when eating raw, live oysters, French consumers in general, and those traditionally seen as "oyster eaters" in particular, consider that they are "drinking the sea", conjuring up iodine and all the images of naturality, purity, lightness and freshness associated with this shellfish. In short, the social representations associated with oysters by consumers identify a healthy and refined food (Debucquet and Merdji, 2004). On the contrary, part of the population retains a very strong aversion towards oysters and their physical properties, all the more so if they did not eat raw oysters often and at a young age in their food education. Processed oysters could thus be a way of removing these fears. In that case, however, it is necessary to analyse expectations and the associated overall perception. Many studies have indeed shown how information or the visual appearance of food influences flavour recognition or overall liking and generates expectations (Mojet and Koster, 2005; Kole, 2009; Delwiche, 2004); a contrast between expected and actual sensory qualities can induce a strong negative affective response focusing on the unexpected sensory qualities (Yeomans et al., 2008). In the case of oyster, the context of the first tasting or first "experience" (Faurion, 1996) contribute strongly to previous social representations associated with this kind of food and could influence the expected sensory qualities.

In this context, could processing overcome the impact of representations and sensory barriers associated with oyster in non-consumers? Or would deep-seated reasons still prevent consumption for non-consumers? On the other hand, would a traditional consumer of fresh oysters be ready to accept a processed product with the risk of losing certain attributes, such as "natural" and "authenticity"? From a theoretical perspective, this problematic leads to analysis of the phenomenon of anchoring as described by Moscovici (1961), that is, how the perception of new products and their sensory qualities are determined by previous representations and the social value associated with this food, which is called by Jodelet 
(1994), the "already in mind". As this topic has received little attention in the literature on

101 sensory and hedonic evaluation, this article will try to fill the gap.

102 The general objective of the paper was to analyse and understand the key drivers in oyster or

103 based-oyster products consumption with a twofold research objective: evaluating the impact

104 of processing and social representation on hedonic perception. To achieve these objectives, a

105 complementary approach was applied. A qualitative approach through individual interviews

106 and focus groups was carried out to catch the conscious and unconscious elements in the

107 consumer perception. Then consumer tests were performed on five oyster-based products in

108 two situations of consumption in order to reach a large range of population in term of ages

109 and professional activities (students and active workers in canteens and families with children

110 and teenagers at home). Products were collected from three seafood companies, partners in

111 the project. The range of products making it possible to illustrate the influence of the degree

112 of processing was composed of a frozen, cooked oyster in a half-shell (C) and four sterilized

113 products presented either in cans for soup $(\mathrm{S})$ hot preparations for toast $(\mathrm{T})$ or in glass jar for

114 oyster butter (B) and potted oyster (P). Oyster was entire in the case of $\mathrm{C}$ product, mixed in $\mathrm{T}$,

$115 \mathrm{~B}$ and $\mathrm{P}$ products and some pieces of oyster were present in $\mathrm{S}$ product. Table 1 gives the main

116 ingredients and characteristics of each product. A preliminary study with a trained panel

117 showed a wide range of sensory characteristics (Cardinal \& Debucquet, 2010) : in appearance,

118 from smooth, light and homogeneous $(\mathrm{P}, \mathrm{B})$ to a more complex product with small pieces and

119 dark colour (T and S); in texture, from a liquid (S) to a paste with different degrees of fat

120 perception $(\mathrm{B}, \mathrm{P}, \mathrm{C})$; in odour with specific marine notes such as seaweed $(\mathrm{T})$ to vegetable $(\mathrm{S})$

121 or garlic $(\mathrm{B}, \mathrm{P})$ or onion and wine for $\mathrm{C}$; in flavour, from marine notes such as seaweed (T, S)

122 to butter and garlic, especially for B and P. The final objective was to identify if in the range

123 of processed products presented, some of them were mainly adapted to a specific target of

124 consumers. 
126 Study 1: Qualitative study - Individual interviews and focus-groups -

127

128

129

130

131

132

133

134

135

136

137

138

139

140

141

142

143

144

145

146

147

148

149

Method

After a first, exploratory stage with in-depth and individual interviews (10 people), four focus-groups of 8 people each (in total 32 people) were made up. During focus-groups, the five products were presented and tasted by the subjects but several projective exercises and open questions were introduced in order to induce spontaneous evocations and collect references to the unconscious, as suggested by Moliner (2001) as a means of accessing social representations. Each focus-group lasted on average $2 \mathrm{~h} 30$. This qualitative stage aimed (1) at identifying the main factors involved in the consumption or non-consumption of oyster-based products, especially those related to previous social representations associated with oysters and to the recipe itself (the perceived compatibility of the ingredients with oysters, the impact of the degree of oyster processing on acceptability) and (2) to set up hypotheses to be tested in the questionnaire (study 2). Subjects were recruited in the Pays de Loire area and the sample was an equal distribution of age classes, gender, educational level and oyster consumers (C) versus non-consumers (NC). For the recruitment, consumers were informed that the session was a discussion on seafood products with a taste session (no information was delivered on the kind of the products) and therefore they were invited to tell what products they generally consumed and what products they never consumed. They did not know that the session focused on oyster.

In addition, a comparative test on taste perception was implemented during the focus-groups, inspired by the psychophysical experiment by Morrot et al. (2001) on odour perception. These authors investigated the interaction between the vision of colours and odour perception through lexical analysis of experts' wine tasting comments. A white wine artificially coloured 
150 red with an odourless dye was described as a red wine in olfactory terms. Analysis showed

151 that the odours of a wine are, for the most part, represented by objects that have the colour of

152 the wine. In our experiment, subjects were offered two samples of the five oyster-based

153 products. The first was a blind test (subjects were told that it was seafood products); for the

154 second, the same five products were offered but they were presented as novel products

155 prepared with oysters. This comparative test was not strictly a sensory test but a projective

156 exercise (Donoghue, 2000) to stimulate verbalization. The aim of this part of the focus-group

157 was in fact to evaluate the influence of previous representations associated with oysters on

158 product perception, especially taste descriptors, and, at the same time, to compare perceptions

159 and assessment of oyster consumers in comparison with non-consumers.

Data analysis

162 An analysis of themes, sub-themes and lexical universes was carried out with data collected

163 during the focus-groups and individual interviews, and, more particularly, the comments of

164 subjects at both stages of the comparative test.

Results : Impact of oyster representations on hedonic perception of processed products

167 The lexical analysis of the comments collected during the comparative test showed huge

168 discrepancies both between the first test (blind test) and the second test (the subjects were

169 informed that the products were oyster-based products) and between oyster consumers and

170 non-consumers. The results showed that taste perception is not only dependent on the first

171 sensory experience but also on the pre-existing representations associated with oysters. Taste

172 perception and, more particularly, taste descriptors effectively changed considerably between

173 the first and second tests: 
174 - we observed that taste initially perceived as "insipid" $(10)^{1}$, mainly among the non-

175 oyster consumers (NC) and mostly recruited from young subjects became in the second test 176 "strong"(7), " too strong”(5), "bitter"(3), “acid”(3), that what was called "an indefinable 177 taste”(9) became "strange”(7), “doubtful taste”(4), "a bad aftertaste"(4), and lastly that a 178 texture initially perceived as "soft"(3), "thick"(8) or "heavy"(7) became "jelly-like"(9), and 179 "viscous"(11). All in all, the lexical registers used after being told of the presence of oysters 180 in the recipes showed that simply mentioning oyster revived the main sources of disgust 181 produced by the consumption of raw oyster, that is: viscosity, stickiness and alive;

182 - on the other hand, the change in lexical register for taste, perceived first as "good" (9) 183 or "pleasant”(11) and becoming "not fine or exquisite enough"(5), "not high-class 184 enough"(6) is mainly observed among the consumers (C). Moreover "Taste of the sea"(11) 185 became for them “good taste but not strong enough because we don't recognize the taste of 186 oyster enough"(8) or sometimes "not natural enough"(7), "chemical”(3), and lastly a 187 “delicious and creamy texture"(8) became "like boiled and over-cooked oysters"(6). All in 188 all, these quotations highlight that all the dimensions confer oysters, in the mind of French 189 oyster eaters, with the status of a refined, exceptional and natural dish.

191 Beyond these differences, the products were less appreciated during the second test by both 192 oyster consumers and non-consumers as proved by highly negative comments and bigger 193 amount of leftovers. The subjects were expecting to find oyster-based products "less fatty",

194 "less pasty" and, in some opinions, "the fatty texture suggests that it was fatty oysters or 195 oysters with soft roe”. These last quotations confirm that oysters are perceived by most 196 people as a diet and healthy food. In others words, in their mind, fat is not compatible with the 197 representations associated with oyster, that is, hints of the sea, coast, iodine, and mineral salts.

\footnotetext{
${ }^{1}$ For the two groups (NC and C) constituted of 16 persons ( 2 focus-groups of 8 persons each), the number in bracket represents the number of citations of each term.
} 
A second part of the focus-groups was dedicated to identifying the boundaries of acceptability

199 as regards recipes and ingredients. As presented in the methodology part, a creativity exercise

200 was implemented during the focus-groups in order to understand what kind of recipes would

201 be accepted or rejected by consumers, according to the nature of the ingredients (meat, fish,

202 fruits, vegetables, dairy products, etc.) and the level of processing of oysters.

203 - Concerning ingredients, the results demonstrated that the association between oysters

204 and meat was rejected by almost everybody. This is an illustration of the impact of cultural

205 habits on acceptability and more particularly of French habits. As oysters are commonly eaten

206 in a raw, live form, the association with meat appears definitively dissonant because of the

207 mixture of "substances", especially "land substances" and lives "sea substances": "They are

208 two different species, from land and sea. So, no! [...]. And moreover, meat is a living

209 substance, as are oysters... That is definitely incompatible!". The case of red meat provoked

210 the greatest disgust, because of the blood: "Red meat is not fully dead, it is still a little bit

211 alive. Look at the blood!", . The risk arising from this quotation is clearly a symbolic risk and,

212 very logically, white meat (such as pork or chicken) or "reified" meat like ham were better

213 accepted in the recipe with oyster-based products. Lastly, vegetables, as more neutral

214 ingredients, or fish, as ingredients from the same universe, did not raise any problems.

215 Concerning the level of processing of oysters and therefore the texture of oyster-based

216 products, the participants in the focus-groups stressed the need to clearly identify each

217 ingredient with regard to the issues of mixing "substances". Consumers and non oyster

218 consumers turned down products that were overly processed, of the paste- or blended-type, as

219 they played a part in excessively denaturing the oysters and were perceived as industrial and

220 suspicious products. While the ideal recipe for the oyster consumers was the cooked oyster in

\footnotetext{
${ }^{2}$ Historians have analysed the importance of the beliefs associated with red meat and blood, especially during the pre-scientific period (Darnon, 1999). A recent research project dedicated to the perception of food germs has shown that blood in red meat is still nowadays perceived as risky because of the survival of the belief in "spontaneous generation" among lay persons (Debucquet, Merdji, Fischler, 2007).
} 
a half-shell, because it maintained a symbolic proximity to raw oysters ("Great! They remain in their shell! They look fresh even if they have been frozen!"), on the contrary, nonconsumers looked for intermediary products, neither too mixed and without big pieces of oyster to keep a symbolic distance from the sources of disgust.

- $\quad$ Regarding sanitary risk, it is interesting to note that during the focus-groups and after presenting the processed oysters, none of the non-consumers spontaneously tackled this issue. Surprisingly, the processing of oysters removed all the fears and anxiety about sanitary risk because the "oyster is dead", that is, in the subjects' minds, in biological and symbolical terms. On the contrary, more people among the raw oyster consumers were suspicious of processed oysters because the process was always perceived as a "denaturation" of the oyster, necessarily using additives and preservatives.

In conclusion, the results of the qualitative study revealed huge differences in the mechanisms of perception of oyster-based products between consumers and non-consumers. Our data suggest the importance of previous representations associated with raw oyster on processed oyster perception in terms of taste, recipe acceptability and risk perception.

Study 2: Quantitative study - Consumer test in real consumption situations -

\section{In staff canteens}

Method

Consumer panel

The French multinational corporation Sodexo, one of the largest food service companies in

244 the world was a partner in the project and offered the opportunity to test products in different 245 staff restaurants. The context of restaurant was particularly interesting because oysters are, in 246 France, almost always consumed in the setting of a social and shared meal. The companies 
were chosen according to their location and their field of activity in order to reach consumers

248 with different profiles. Three cities that differ from one another in terms of distance from the

249 sea were selected: Nantes, Tours and Lyon. Ifremer, a Marine Research Institute with a

250 consumer population involved in marine questions and the Ecole des Mines, a school of

251 Engineering mainly composed of young consumers, were the two companies chosen in

252 Nantes to test products in their Sodexo restaurants. In Tours, the company selected was

253 Sanofi, from the pharmaceutics sector, and finally Areva, a company working in the nuclear

254 field, in Lyon made it possible to test people in the research department. The four self-service

255 restaurants were different in terms of their mean numbers of daily customers and finally the

256 number of participants in the consumer test was respectively for each restaurant, 155, 177, 87

257 and 62. The whole panel's characteristics included the four canteens are presented in Table 2.

258 The amount of oyster eater in this population reached $76 \%$.

Procedure

261 Tests were performed between December 2009 and April 2010. Products were prepared in each self-service restaurant according to industrial recommendations and were presented at the entry of the restaurant on a plate prepared for each customer. To lighten the test for consumers, the five products were presented on two successive days with a presentation of three products the first day $(\mathrm{P}, \mathrm{S}, \mathrm{T})$ and two products $(\mathrm{B}, \mathrm{C})$, the second day. Products were presented simultaneously on the same plate and consumers tasted the products according to a balanced order in the questionnaire. As the tests lasted for two days, all consumers did not taste necessarily all the products. Each person was informed that the products were oysterbased products and was invited to test them during their lunch. Customers were free to take

270 them or not. After acceptance, the same questionnaire was distributed in each restaurant to 271 collect their opinion. They were invited to give a few negative and/or positive words after 272 tasting each product and to rate their overall liking with a score from 0 to 10: dislike 
273

274

275

extremely (0), like extremely (10) and to express their perception of naturality, not at all (0), quite natural (10). Personal information such as age, gender, educational level and consumer (C) or non-consumer (NC) of raw oyster was asked for at the end of the session. In the paper, $\mathrm{NC}$ refers to non-consumers of raw oyster, the traditional way of eating oysters in France.

Data analysis

Consumer data results were expressed as a mean \pm standard deviation (SD). In consumer test, estimation of the effect of each variable (social and demographic characteristics, traditional oyster consumer) on overall liking was performed by analysis of variance on all consumer scores with products and each of these variables as independent factors. The main effects and interaction between factors were tested. The analysis of qualitative data (negative and/or positive words associated to each product after tasting) was only performed on questionnaires from the home tests where description was more detailed and richer than in restaurants.

The scores for overall liking and "naturality" attributed by consumers to each product are presented in Table 3. The general mean for overall liking scores for all consumers highlights a significant difference between the products. The cooked oyster in a half-shell obtained the highest score $(6.9 \pm 1.9)$ followed by soup $(6.2 \pm 2.4)$, potted oyster $(6.1 \pm 2.1)$, hot toast $(5.9$ $\pm 2.2)$ and finally oyster butter $(5.7 \pm 2.0)$, but no significant difference appeared between the last three products. Food habits related to raw oyster consumption had a significant effect $(p=0.03)$ on overall liking as traditional raw oyster consumers gave higher scores to products compared to those of non-consumers. No interaction appears between the variables "usual oyster eater" and products which means a same general trend in overall liking for C and NC. Analysis of variance performed over all the consumer data of liking with products and gender 
as independent factors did not show any significant difference between scores attributed by women or men $(\mathrm{p}=0.43)$. Educational level and age did not lead to a significant difference either, $(\mathrm{p}=0.11$ and $\mathrm{p}=0.79$, respectively).

\section{At home}

Method

Consumer panel

145 consumers from 68 households on the Tastenet panel took part in the study. The Tastenet panel was composed of volunteers for consumer tests at home on fish and fish products selected by the French Research Institute Ifremer through the company's staff (friends, family, neighbours). The answers of all family members older than 11 years were taken into account. The majority of theses families lived in an urban area (Nantes). The main characteristics of this at home consumer panel are presented in Table 2.

313 Consumer tests were performed between March and April 2010. Families were provided with

314 the five oyster-based products (here, in their packaging) and a questionnaire for each product

315 and each family member. There was a total freedom to choose the order of consumption of

316 the 5 products as well as the time and the situation of consumption but it was recommended that the products be tested one by one on different days depending on the choice of the family

318 and that the product be prepared according to the directions for use on the packaging. The

319 consumption was organised with the family members previously identified in this home. The

320 same questionnaire as at the self-service restaurants was presented. 
323 The same kind of analysis was applied on overall liking data obtained in staff canteens and at

324 home. Qualitative information obtained from the open questions, especially the negative

325 and/or positive words associated with each product that respondents were asked to provide

326 after tasting, was analysed using textual analysis software called ALCESTE $^{3}$ version 2010.

327 This software makes it possible to treat corpora of discourses and to separate statements into

328 classes, using a downwards-hierarchical classification on the basis of co-occurrence of words

329 (Reinert 2002). The classification of the respondents' terms established by ALCESTE was

330 based on the idea that the words used by each respondent were chosen according to his or her

331 particular mental space that constitutes the person's framework of reference (Reinert 1993).

332 When data comes from a panel of respondents, it helps to analyse social representations, each

333 class of word used often unconsciously by respondents then resulting from an anchoring

334 process (Debucquet, 2011), in accordance with the theory of representations developed by the

335 French school of social psychology (Moscovici 1961; Jodelet 1994; Moliner 2001) which

336 shows how representations are embedded in a social and cultural context. This analysis was

337 performed on questionnaires from the home tests where description was more detailed and

338 richer. Moreover, Chi-square tests were carried out by ALCESTE software to identify

339 significant associations $(\mathrm{p}<0.05)$ of each class of words with oyster-based products,

340 sociodemographic profiles, and oyster consumers (C) or non-consumers (NC).

Results : Overall liking and hedonic perception at home

343 Even if our research is not focused on the consumption context effect, previous studies have

344 shown differences in overall liking between at home test and other situations, it is the reason

345 why results from at home are presented separately. The results of the consumer tests

\footnotetext{
${ }^{3}$ Analyse des Lexèmes Co-occurrents dans les Enoncés Simples d'un Texte (Analysis of co-occurent lexemes in simple wordings of a text)
} 
performed at home showed the same order in overall liking as those obtained in staff canteens

347 but the scores attributed were generally lower, except for cooked oyster (Table 4). The highest

348 scores were attributed to cooked oyster and soup with a mean score of $6.9( \pm 2.0)$ and $5.6( \pm$

349 2.6) respectively. No significant difference appeared between the other three products. A

350 higher perception of naturality was also associated with the preferred products. In this test,

351 even though oyster consumers, also called "oyster eaters", had better rated soup and potted

352 oyster, the difference in overall liking between "oyster eater" and non-oyster consumer was

353 not significant $(\mathrm{p}=0.29)$. As observed in the restaurants, gender and educational level did not

354 affect the overall liking scores. On the other hand, age had a significant effect $\mathrm{F}_{4,4}=4.5$,

$355 \mathrm{p}=0.001$ and the youngest consumers generally attributed lower scores, especially to the soup,

356 hot toast and cooked oyster compared to the upper age class. It is also interesting to note the

357 frequency of refusal for each product (Table 4). Cooked oyster, hot toast and soup were the 358 products with the highest frequencies of non-consumption, respectively, $17.1 \%, 14.5 \%$ and

$35913.0 \%$ of the whole panel compared to $4.8 \%$ and $4.1 \%$ respectively for potted oyster and

360 butter. Generally this refusal came from the youngest fraction of the population tested, in this

361 case, the children in the families and also from the non consumers of raw oyster (Table 4).

362 Once the consumption barrier had been removed and the product tested, consumers provided 363 their hedonic evaluation through a score for overall liking as well as the main descriptors 364 describing the positive and/or negative characteristics for each product. The results from the 365 ALCESTE data processing made up of positive and negative words collected through the 366 open questions in the questionnaire gave some explanations to the perception and overall 367 liking of each product. From the positive evocations provided by the subjects, 2655 specific words were analysed and $74 \%$ of the statements classified into 3 classes (Table 5). The largest class (Class $1-55.0 \%$ of classified statements) focused on the taste of oyster as socially

370 perceived in France: a refined and exquisite taste, combined with the image of a festive, rare 
and luxury food. The second (Class $2-37.0 \%$ ) deals with the texture and appearance of the products in relation to convenience issues (ease of preparation, easy to spread). The last, and smallest (Class $3-8.0 \%$ ), expresses the need to compare these unknown products with more familiar fish products, such as fish soup and potted fish. Table 5 gives the significant associations $(\mathrm{p}<0.05)$ between these classes and variables as products, socio-demographic profiles and consumer type ( $\mathrm{C}$ or $\mathrm{NC})$. The butter was associated with class 1 , the soup with class 3 and the cooked oyster in a half-shell with class 2. Moreover, older people, men, "raw oyster eaters" (C), and those introduced to oysters early (before the age of ten) were significantly associated with class 1 , young people, women, students, and those introduced to oysters rather late (after the age of 20) with class 2, and lastly, people of intermediary age introduced late to oysters with class 3 . These results highlight the opposition between younger and older generations regarding food issues (convenience and innovation as regards recipe and way of consumption (aperitif, short meal with friends) versus search for taste and authenticity) and specifically the influence of oyster consumption ("non-oyster eaters" versus “traditional oyster eaters").

From the negative evocations provided by subjects, a larger corpus of 3099 specific words was analysed and $61 \%$ of the statements were classified into 4 classes (Table 6). The largest class (Class $1-37.0 \%$ of the statements classified) contains a lexicon highlighting doubt, fear, and anxiety towards the products as if exposure to oyster-based products would reactivate all the fears associated with raw oyster consumption. Class $2(29.0 \%)$ focuses on the dissonance resulting from the fatty and pasty characteristic of certain products, perceived as sticky and sickly (“too much cream and butter”). In consumers' minds, oysters are a light, healthy product with small quantities of fat. Class $3(25.0 \%)$ deals with the taste of the oyster itself, oyster consumers conflicting with non-oyster consumers. The former were deeply concerned about the tastelessness and weak oyster taste of the products whereas the latter 
often judged the taste of oyster to be "too strong". Lastly, the smallest class (Class $4-9.0 \%$ )

397 focuses on the disgust induced by the presence of big pieces of oyster in the processed

398 products. Concerning the significant associations, the soup and hot toast were associated with

399 class 1, the butter and potted oyster with class 2, the cooked oyster in a half-shell with class 3 ,

400 and the potted oyster with class 4 . These results are consistent with the sensory

401 characteristics previously described by a trained panel (data not shown). Moreover, cooked

402 oyster consumers, born inland and introduced very late to oyster consumption (after the age of

403

36) were significantly associated with class 1 , the "raw oyster eaters" (C) from coastal areas

and older people with class 2, young people and students with class 3 and lastly the non-

oyster consumers (NC), neither raw nor cooked, with class 4. Once again, these results

highlight the impact of previous representations on hedonic evaluation and overall liking, which translated into two opposite lexicons referring to two segments of population, "oyster eaters" and non-consumers.

\section{DisCUSSION}

411 We proposed in this paper to inquire on the key drivers in oyster or based-oyster products 412 consumption and more specifically to focus on the impact of processing and social representation on hedonic perception. Theoretical and methodological issues will be discussed

414 with regards to main results of the different studies.

417 To review the expected results briefly: it was anticipated that processing oysters would 418 decrease disgust among non consumer of raw oysters (NC) and that, at the same time, social representations associated with raw oyster consumption would influence hedonic perception

420 of oyster-based products both among consumers (C) and non consumer (NC). Analysis of 
data from opened questions (study 2) revealed major differences between consumer (C) and non consumer $(\mathrm{NC})$ as expected. Indeed, significant associations $(\mathrm{p}<0.05)$ between lexical classes, products, socio-demographic profiles and consumer type have been found. Consumer (C), older people and those introduced to oyster early were associated with both a class (positive associations) focused on refined and exquisite taste of some products and also a class (negative associations) focused on the tasteless and weak oyster taste of others products. On the other hand, non consumer (NC), young people and people introduced late to oyster were associated both with a class (positive associations) focused on convenience issues but also with a class (negative associations) focused on anxiety, fear and doubt, oyster-based products consumption reviving unconsciously the main sources of disgust (live, viscous and sticky properties) associated with raw oyster consumption. The comparative test (blind test vs test with information) (Study 1) performed during focus-groups confirmed these results when comparing statements of consumers and of non consumers. Our results match previous research on how the congruence or not of expected and actual flavour has an influence on hedonic evaluation (Yeomans et al., 2008). Expanding on what Faurion (1996) wrote, "flavour is not an intrinsic property of a stimulus but the meeting of a food and an eater", our research contributes to better understanding of how previous representations predetermined hedonic evaluation. This issue of expected versus actual flavor seemed to be crucial but covered different meanings according to the kind of consumers $(\mathrm{C})$ versus $(\mathrm{NC})$, in accordance with the theory of social representations and especially the anchoring process (Moscovici, 1961). Finally, our results match and enrich those of Desmet and Schifferstein (2008), who described the impact of positive and negative emotions on food experience, taste perception being namely influence by sensory attributes, experienced consequences, anticipated consequences and personal or cultural meanings; here the impact of social 
representations associated with oyster consumption, and more broadly speaking, the status of 446 this kind of food in culture have been highlighted.

447 If we consider now the overall liking of the processed products measured in restaurant and in 448 home (study 2), results showed the same order in the overall liking ranking, with significant 449 differences between cooked oyster (C) and soup (S), the two preferred products and potted 450 oyster (P), hot toast (T) and oyster butter (B), the three less preferred ones. The ranking of 451 products according to the criteria of "naturality perceived" is in the same order and identical 452 in both situations again and is congruent with the opposition observed in previous sensory 453 characterization. This result highlights the importance of the recipe and the nature of 454 ingredient on the perception; the more the recipe is natural the more the image of the product appears congruent with the positive images associated with seafood and sea more widely, as 456 presented before and confirmed with the creativity exercise during focus-groups (study 1). In accordance with these results, data collected through open questions in the questionnaire 458 (study 2) arose also the fat issue and mainly the incompatibility of fat with oyster. This result 459 gave an other illustration of the importance of social representations associated with oyster, 460 their status in French food culture, their health value, and their source (images of the sea). As 461 mentioned in introduction, oyster is perceived as a luxury and refined food, partly because of 462 its healthy properties, real but also assumed because of the positive imaginary associated with 463 seafood.

464 Regarding the relationship between consumer profile and overall liking, results of both tests 465 (at home and restaurant test) did not show any effect of gender and educational level. 466 Contrary to raw oyster consumption which can participate, according to the expression of 467 Bourdieu (1979) in a mechanism of "distinction", oyster-based products seem to have lost 468 their prestigious status because of the industrial process in itself and exactly like for triploid 469 oysters (Debucquet \& Merdji, 2004). However some contradicting results have been observed 
concerning the influence of others variables on overall liking and especially the type of consumer (C) vs (NC) and age. In restaurant test, food habits related to raw oyster consumption had a significant effect $(\mathrm{p}=0.03)$ on overall liking (scores of consumer $(\mathrm{C})$ higher than scores of non-consumer (NC)) while no significant effect has to be noticed regarding home test. This difference could be attributed to a smaller panel size in home test compared to restaurant test. Conversely, age had a significant effect $\left(\mathrm{F}_{4.4}=4.5, \mathrm{p}=0.001\right)$ on overall liking (scores of youngest consumers lower than oldest ones) while no significant effect has been noticed in restaurant test. The higher rate of under 25 years-old consumers, $27.6 \%$ at home vs $14.6 \%$ in staff restaurants, could explain this difference. Results from focus-group and opened questions in study 2 are consistent with the study of Girard \& Mariojouls (2003) namely the relation between the type of consumer and age; oyster eaters being more frequent among people over the age of 50 while non consumer were more often recruited among the youngest.

This question arises more widely the issue of first exposure and first tasting and their impact on further sensory experiences as analyzed mainly with children (Loewen and Pliner, 1999). Individuals' memories of flavour from childhood are typically for foods that are remembered as very palatable or very unpalatable (Barker, 1983). During individual interviews and focusgroups, most of the non-consumers who felt a strong disgust for raw, live oysters were exposed rather late (in average, after 18 years old) to this kind of food unlike the consumers who were used to eating it from a young age, sometimes in the first years of their live even. Thus, it appears that the earlier the subjects were exposed to raw, live oysters, the less they considered them unpalatable and the more willing they were to taste these new oyster-based products.

Finally, these results bring up the question of the role of both first tasting and social representations, especially for non consumers having to face with a previous disgust for the 
animal itself. Martins and Pliner (2005) have shown in the case of food from animal origin the

496 impact of beliefs on hedonic perception, as well as the impact of the assumed negative 497 consequences of eating such foods on acceptation or rejection. The frequency of refusal for 498 each product in home test (study 2) gave interesting information: cooked oyster (C), hot toast 499 (T) and soup (S) are products with the highest frequencies of non-consumption, respectively $50017.1 \%, 14.5 \%$ and $13.0 \%$ compared to $4.8 \%$ and $4.1 \%$ for potted oyster and butter. 501 Moreover, this refusal came from the youngest fraction of the population tested, children in 502 the families and also from non-consumer $(\mathrm{C})$. These results seem to be relevant: disgust and refusal is more associated with products close to the original form of animal (cooked oyster in half-shell) or containing small pieces of oyster (hot toast and soup). These results highlight here again the impact of processing, as a way to "reify" more or less strongly oyster, on the acceptability of the oyster-based products.

\section{Methodological issues}

509 This complementary approach, including a preliminary sensory analysis with a trained panel, 510 individual interviews and focus groups, and consumer tests made it possible to triangulate the 511 results. Qualitative results from individual and group interviews matched closely those of consumer tests, particularly the open questions included in the questionnaire and scores of the overall liking for the five oyster-based products. On the other hand, the preliminary sensory 514 approach made it possible to bridge some product characteristics, through descriptors, and 515 overall consumer liking, with the latter strongly dependent on the consumption or not of raw 516 oysters. For instance, a strong odour/taste of garlic or seaweed can be valued by nonconsumers and symmetrically rejected by consumers: for the former, it was an original and new odour/taste that did not recall that of oyster, whilst for the latter, it was a "tasteless" product because they did not recognize the "genuine taste of oyster". 
One last methodological consideration could be the impact of the tests 'context on the overall

521 liking. Initially, we choose two contexts for the tests, home test and staff canteens test, to reach various profiles of consumers in terms of age, gender and professional activities, active workers, students, teenagers living still in their family, etc. Even though the effect of the context was not a main objective of our research, we can note that the ranking of the overall liking of the 5 products was the same in both cases but the scores attributed at home were generally lower than those given in staff restaurants. Most of the studies where Standardised Situation Tests (SST) and Home Use test have been compared reported higher liking scores in SST than in HUT scores (Boutrolle, Arranz, Rogeaux, \& Delarue, 2005; Kozlowska et al., 2003; Murphy, Clark, \& Berglund, 1958). However, in a few cases, the reverse has been observed (Daillant-Spinnler \& Issanchou, 1995; Hellemann, Mela, Aaron, \& Eleri Evans, 1993). For example for high fat version of a cream cheese, consumers were more severe at home than in laboratory. Authors argued "that assessors overestimated the products in the laboratory because during home consumption consumers refer to a broader range of products (i.e. other brands)" and also "the possibility that assessors like to please the experimenter when they rate the products in the laboratory". In our case, the lower scores in home tests could be explained by the status of the oyster-based products themselves and the strong involvement attached to raw oyster consumption in France. As mentioned in the introduction, just as well for consumer and non consumer, raw oyster is a luxury and "high- symbolic value" food strongly associated to family consumption for specifics events. Moreover, as in home tests the families were given the products with their packaging (for 4 products) they became probably more aware of the fact that oyster-based products were processed food, all the more so since the ingredient list was on packaging. Furthermore, it is likely that the family environment developed higher involvement for its members and may therefore have led to more critical analysis (Boutrolle, 2007; Stroebele and De Castro, 2004; de Graaf, 2005). 
545 Conversely, the social interaction in staff canteens and the limited portion sizes presented to

546 the consumers may explain a generally better evaluation (King, 2004, Boutrolle, 2007).

\section{CONCLUSION}

550 In conclusion, this study showed the impact of social representation, strengthened by the

551 specific initial product characteristics and the positive or negative effects of the first exposure

552 and tasting of raw oyster on perception and its repercussion on expectations or fears related to 553 processed oyster-based products. For instance, contrasted behaviours may appear depending 554 on the initial profile of the consumer, traditional raw oyster consumer or non-consumer. The 555 results allowed us to identify two different market orientations, the first adapted to traditional 556 raw oyster consumers, rather old, with a range of products as close as possible to the natural 557 product, where the oyster taste is clearly recognised; the second aimed at non-consumers of 558 raw oysters, rather young, and proposing products with adapted characteristics, for example 559 an attenuated odour or taste of oyster and a texture with few or even no oyster pieces. For 560 non-raw, live oyster consumers, the more the oyster was processed (such as butter and potted 561 oyster), the less the sources of disgust identified by Rozin and Fallon (1987) and Kolnai 562 (1998) were effective. In their minds, the process played a part in reifying the oyster 563 substance and reducing the aversion. This segmentation also covers expectations of 564 consumers in terms of age distribution, and confirms the opposition between younger and 565 older people. Processing could make possible generational transfer in oyster consumption if 566 these expectations are fulfilled. Nevertheless, the first consumption or the willingness to 567 consume an oyster or an oyster-based product remains a hurdle in the case of non-consumers. 568 As suggested before, the positive effect of early and frequent exposure, for instance in 569 canteens or university cafeterias, should be exploited in order to have a long-term influence 
570 on food choice and the preferences of the younger consumers. However, one of the main

571 limits of our research is the lack of information on real uses and context of consumption. Are

572 these products still adapted to festive and refined consumption according to the French

573 traditional habit or doomed to a more ordinary consumption? The question could be answered

574 through further research.

575

\section{Acknowledgements}

577 This study, carried out with the support of the Pôle Agronomique Ouest and Valorial, was

578 funded by the Brittany and Pays de la Loire regions. The products used in the study were

579 processed by three industrial partners: Cuisine Gourmande, La Belle Iloise and Youinou.

580 Thanks to Sodexo and especially the staff in the four restaurants in Lyon, Nantes and Tours

581 for their efficient organization in the consumer tests. 


\section{REFERENCES}

583 Barker, L.M. (1983). Building memories for foods. In Barker, L. M. (Ed.) The psychobiology of 584 human food selection. Westport: AVI

585 Bourdieu, P. (1979). La distinction. Paris, Editions de Minuit.

586 Boutrolle, I., Arranz, D., Rogeaux, M., \& Delarue, J. (2005). Comparing central location test and home use test results: Application of a new criterion. Food Quality and Preference, 16(8), 704713.

Boutrolle, I., Delarue, J., Arranz, D., Rogeaux, M., \& Koster, E. P. (2007) Central location test vs. home use test: Contrasting results depending on product type. Food Quality and Preference 18(3), 490-499.

Cardinal, M., \& Debucquet, G. (2010). De nouveaux produits pour lever les freins à la consommation d'huîtres et élargir les marchés pour les PME ? Adéquation entre perceptions du consommateur et degré de transformation du produit. Rapport de recherche de fin de contrat. Projet régional Bretagne et Pays de la Loire. Ifremer - Audencia.

Daillant-Spinnler, B., \& Issanchou, S. (1995). Influence of label and location of testing on acceptability of cream cheese varying in fat content. Appetite, 24(2), 101-105.

Darmon, P. (1999) L'homme et les microbes. Paris ; Fayard

Debucquet, G., \& Merdji, M. (2004). Triploïd oysters. Slow Food, 46, 68-75.

600 Debucquet, G., Merdji, M. \& Fischler, C. (2007). La perception des contaminations alimentaires par 601 les consommateurs : analyse des représentations et des pratiques associées à la prévention du risque microbien. 12èmes Journées de Recherche de Marketing de Bourgogne, Dijon, 8-9 novembre 2007.

Debucquet, G. (2011). Considérer les normes sociales et culturelles pour une meilleure acceptation des innovations technologiques en alimentation: les leçons du rejet des aliments génétiquement modifiés (OGM). Management International, 15(4): 49-68.

Delwiche, J.F. (2004). The impact of perceptual interactions on perceived flavor. Food Quality and 

Consumer Sciences, 28, 47-53.

611 de Graaf, C., Cardello, A.V., Matthew Kramer, F., Lesher, L. L., Meiselman, H.L., \& Schutz, H.G. 612 (2005). A comparison between liking ratings obtained under laboratory and field conditions: The 613 role of choice. Appetite, 44(1), 15-22

614 Desmet, P.M.A., \& Schifferstein, H.N.J. (2008). Sources of positive and negative emotions in food experience. Appetite, 50, (2-3), 290-301

616 Faurion, A. (1996). Le goût : un défi scientifique et intellectuel, Psychologie française, 41(3), 217-225

617 Fischler, C. (1990). L'homnivore. Paris, Odile Jacob.

618 France Agrimer, (2010). Les Filières Pêche et Aquaculture en France, Données Statistiques 2009.

619 Girard, S., \& Mariojouls, C. (2003). French consumption of oysters and mussels analysed within the 620 European market. Aquaculture Economics and Management, 7, 319-333.

621 Hellemann, U. A., Mela, D. J., Aaron, J. I., \& Eleri Evans, R. (1993). Role of fat in meal acceptance. Food Quality and Preference, 4(1-2), 90.

Jodelet, D. (1994). Représentations sociales : un domaine en expansion. In D. Jodelet (Eds), Les représentations sociales (pp. 31-62). Paris, PUF.

King, S. C., Weber, A. J., Meiselman, H. L., \& Lv, N. (2004). The effect of meal situation, social interaction, physical environment and choice on food acceptability. Food Quality and Preference, $15(7-8), 645-653$.

Kole, A. P. W., Altintzoglou, T., Schelvis-Smit, R. A. A. M., \& Luten, J. B. (2009). The effects of different types of product information on the consumer product evaluation for fresh cod in real life settings. Food Quality and Preference, 20(3), 187-194.

Kolnai, A. (1998). The standard modes of aversion: Fear, disgust and hatred. Mind, 107(427), 581595.

Kozlowska, K., Jeruszka, M., Matuszewska, I., Roszkowski, W., Barylko-Pikielna, N., \& Brzozowska, A. (2003). Hedonic tests in different locations as predictors of apple juice consumption at home in elderly and young subjects. Food Quality and Preference, 14(8), 653-661. 
636 Loewen, R., \& Pliner, P. (1999). Effects of prior exposure to palatable and unpalatable novel

637 foods on children's willingness to taste other novel foods. Appetite, 32, 351-366

638 Martins, Y., \& Pliner, P. (2005). Human food choices: an examination of the factors underlying 639 acceptance / rejection of novel and familiar animal and non animal foods. Appetite, 45, 3, 214-224.

640 Mojet, J., \& Koster, E.P. (2005). Sensory memory and food texture. Food Quality and Preference, 16, $641 \quad 251-266$.

642 Moliner, P. (2001). Formation et stabilisation des représentations sociales. In P. Moliner (Eds), La

643 dynamique des représentations sociales (pp. 15-41). Grenoble, PUG.

644 Morrot, G., Brochet, F., \& Dubourdieu, D. (2001). The color of odors. Brain and Language, 79, 309645320.

646 Moscovici, S. (1961). La psychanalyse, son image et son public. Vendôme, Presses Universitaires de $647 \quad$ France.

648 Murphy, E. F., Clark, B. S., \& Berglund, R. M. (1958). A consumer survey versus panel testing for 649 acceptance evaluation of Marine sardines. Food Technology, 12, 222-226.

650 Reinert, M. (1993). Quelques problèmes méthodologiques posés par l'analyse de tableaux "Enoncés X 651 Vocabulaire". JADT 1993 - 2èmes Journées internationales d'Analyse statistique des Données 652 Textuelles, Montpellier.

653 Reinert, M. (2002). Les "mondes lexicaux" et leur "logique" à travers l'analyse statistique de divers 654 corpus. JADT 2002 - 6èmes Journées internationales d'Analyse statistique des Données Textuelles.

655 Rozin, P., \& Fallon, A. E. (1987). A perspective on disgust. Psychological Review, 94,23-41.

656 Stroebele N., \& De Castro, J.M. (2004). Effect of ambience on food intake and food choice. Nutrition, $657 \quad 20,821-838$.

658 Yeomans, M.R., Chambers, L., Blumenthal, H., \& Blake, A. (2008). The role of expectancy in sensory 659 and hedonic evaluation: the case of smoked salmon ice-cream. Food Quality and Preference, 19, $660 \quad 565-573$. 
$663{ }^{1}$ Analyse des Lexèmes Co-occurrents dans les Enoncés Simples d'un Texte (Analysis of co-occurent lexemes in 664 simple wordings of a text)

665

$666{ }^{2}$ For the two groups ( $\mathrm{NC}$ and $\mathrm{C}$ ) constituted of 16 persons ( 2 focus-groups of 8 persons each), the number in

667 bracket represents the number of citations of each term.

668

669

$670{ }^{3}$ Historians have analysed the importance of the beliefs associated with red meat and blood, especially during

671 the pre-scientific period (Darnon, 1999). A recent research project dedicated to the perception of food germs has

672 shown that blood in red meat is still nowadays perceived as risky because of the survival of the belief in

673 “spontaneous generation” among lay persons (Debucquet, Merdji, Fischler, 2007).

674

675

676

677

Table 1. Oyster- based product characteristics: form, ingredients, presentation and preparation

\begin{tabular}{cccc}
\hline & $\begin{array}{c}\text { Oyster based } \\
\text { products }\end{array}$ & $\begin{array}{c}\text { Main ingredients and } \\
(\% \text { of oyster in recipe) when recipe available }\end{array}$ & Presentation and product preparation \\
\hline $\mathrm{S}$ & Soup & Oyster (15),vegetables, spices & Metallic can; warm in a pan \\
$\mathrm{P}$ & Potted oyster & Oyster (30), cream, onion, white sauce, butter, garlic & Glass jar, cool before spreading \\
$\mathrm{B}$ & Oyster butter & Oyster (43), cream, butter, white sauce, onion, garlic & $\begin{array}{c}\text { Glass jar, cool before spreading } \\
\text { T }\end{array}$ \\
Hot toast & Oyster (17.5), seaweed, carrot, onion & $\begin{array}{c}\text { Metallic can; spread on bread and toast 5 } \\
\text { min in an oven }\end{array}$ \\
$\mathrm{C}$ & Frozen oyster & whole oyster with sauce in a half-shell & Cook 10 min in an oven
\end{tabular}

678

679

680 
682 Table 2. Characteristics of the staff restaurant consumer panel and at-home consumer panel

683

\begin{tabular}{lcc}
\hline & At-home panel & Staff restaurant panel \\
\hline Gender (\%) & & \\
Female / Male & 56.2 / 43.8 & $41.1 / 58.9$ \\
Age (years) (\%) & & \\
$<$ 25 & 27.6 & 14.6 \\
$26-35$ & 9.7 & 24.0 \\
$36-45$ & 21.4 & 24.1 \\
$46-55$ & 26.2 & 20.1 \\
+55 & 15.2 & 17.2 \\
Educational level $^{1}(\%)$ & & 7.6 \\
Low & 29.7 & 33.1 \\
Middle & 31.9 & 59.3 \\
High & 27.5 & \\
Oyster eater (\%) & & $76.0 / 24.0$ \\
$\quad$ Yes / No & $74.5 / 25.5$ & 481 \\
\hline Respondents (Total) & 145 &
\end{tabular}

$684{ }^{1}$ Low educational level: elementary school; middle educational level: secondary school and middle degree 685 professional education; high educational level: secondary school and higher educational level, higher degree of 686 professional education, university or higher

687

688

689

690 
Table 3. Overall liking in staff restaurant test (mean and standard deviation) according to socio-demographic variables and perception of "naturality"

\begin{tabular}{|c|c|c|c|c|c|c|c|c|}
\hline & \multirow[t]{2}{*}{ Factors } & \multirow{2}{*}{$\begin{array}{l}\text { F and } p \\
\text { values } 1\end{array}$} & \multirow[t]{2}{*}{ Factor level $^{2}$} & \multicolumn{5}{|c|}{ Products } \\
\hline & & & & $\mathrm{P}$ & $\mathrm{B}$ & $\mathrm{T}$ & $\mathrm{S}$ & $\mathrm{C}$ \\
\hline \multirow{12}{*}{$\begin{array}{l}\text { Overall } \\
\text { liking }\end{array}$} & Consumer & $\mathrm{F}_{4,1}=4.66$ & $C^{b}$ & $6.0(2.0)$ & $5.7(2.0)$ & $6.1(2.1)$ & $6.3(2.3)$ & $7.0(1.8)$ \\
\hline & Type & $\mathrm{p}=0.03$ & $\mathrm{NC}^{\mathrm{a}}$ & $6.2(2.4)$ & $5.7(2.4)$ & $5.2(2.4)$ & $5.7(2.5)$ & $6.7(2.2)$ \\
\hline & Age & $\mathrm{F}_{4,4}=0.42$ & $<25$ & $6.4(2.1)$ & $6.6(2.1)$ & $5.0(2.4)$ & $5.5(2.4)$ & 7.7 (1.4) \\
\hline & & $\mathrm{p}=0.79$ & $26-35$ & $5.8(2.0)$ & $6.0(2.0)$ & $5.8(2.2)$ & $6.1(2.2)$ & $7.0(2.1)$ \\
\hline & & & $36-45$ & $5.9(2.2)$ & $5.8(2.1)$ & $6.2(2.5)$ & $6.5(2.6)$ & $7.0(1.9)$ \\
\hline & & & $46-55$ & $6.0(2.3)$ & $5.0(1.8)$ & 6.4 (1.9) & $6.2(2.6)$ & $6.6(1.9)$ \\
\hline & \multirow{3}{*}{ Gender } & & +55 & $6.1(2.1)$ & $5.2(2.2)$ & $6.3(2.0)$ & $6.6(2.1)$ & $6.7(1.6)$ \\
\hline & & $\mathrm{F}_{4,1}=0.62$ & Male & $5.9(2.0)$ & $5.7(1.9)$ & $5.7(2.2)$ & $6.3(2.2)$ & $6.9(1.8)$ \\
\hline & & $\mathrm{p}=0.43$ & Female & $6.2(2.3)$ & $5.6(2.2)$ & $6.2(2.2)$ & $6.1(2.4)$ & $7.0(1.8)$ \\
\hline & \multirow{3}{*}{$\begin{array}{l}\text { Educational } \\
\text { level }\end{array}$} & $\mathrm{F}_{4,2}=2.15$ & Low & $6.5(2.2)$ & $6.1(2.5)$ & $7.5(1.7)$ & $6.3(2.4)$ & $6.9(2.8)$ \\
\hline & & $\mathrm{p}=0.11$ & Medium & $6.1(2.2)$ & $5.8(1.8)$ & $5.8(2.4)$ & $5.8(2.2)$ & $7.1(1.8)$ \\
\hline & & & High & $5.8(2.1)$ & $5.5(2.1)$ & $5.8(2.1)$ & $6.6(2.3)$ & $6.9(1.7)$ \\
\hline $\begin{array}{l}\text { Overall } \\
\text { liking }\end{array}$ & Product & $\begin{array}{l}F_{4,1073}=10.7 \\
p=0.000\end{array}$ & General mean & $6.1(2.1)^{\mathrm{ab}}$ & $5.7(2.0)^{\mathrm{a}}$ & $5.9(2.2)^{\mathrm{ab}}$ & $6.2(2.4)^{b}$ & $6.9(1.9)^{\mathrm{c}}$ \\
\hline $\begin{array}{l}\text { Percepti } \\
\text { "naturali }\end{array}$ & & $\begin{array}{l}\mathrm{F}_{4,1006}=13.4 \\
\mathrm{p}=0.000\end{array}$ & General mean & $5.6(2.5)^{b}$ & $5.1(2.3)^{\mathrm{a}}$ & $5.85(2.3)^{b}$ & $6.4(2.3)^{c}$ & $6.7(3.8)^{\mathrm{c}}$ \\
\hline
\end{tabular}
$\mathrm{p}=0.000$

696 as independent variables

$697{ }^{2}$ Factor levels with different letters are significantly different at $p<0.05$ 
699 Table 4. Overall liking and perception of "naturality" in the at home test (mean and standard 700 deviation)

\begin{tabular}{|c|c|c|c|c|c|c|c|c|}
\hline & Factor & $\begin{array}{l}F \text { and } p \\
\text { values }\end{array}$ & Factor level $^{2}$ & $\mathrm{P}$ & B & $\begin{array}{l}\text { Products } \\
\mathrm{T}\end{array}$ & $\mathrm{S}$ & $\mathrm{C}$ \\
\hline \multirow{13}{*}{$\begin{array}{l}\text { Overall } \\
\text { liking }\end{array}$} & Consumer & $\mathrm{F}_{4,1}=1.1$ & $\mathrm{C}$ & $5.0(2.3)$ & $4.7(2.5)$ & $5.0(2.7)$ & $6.8(2.6)$ & $6.9(2.1)$ \\
\hline & Type & $\mathrm{p}=0.29$ & $\mathrm{NC}$ & $4.4(2.2)$ & $5.1(2.4)$ & $5.1(2.4)$ & $5.0(2.5)$ & $6.7(1.9)$ \\
\hline & \multirow[t]{5}{*}{ Age } & $\mathrm{F}_{4,4}=4.5$ & $<25^{\mathrm{a}}$ & $4.8(2.3)$ & $4.8(2.5)$ & $5.0(2.5)$ & $4.3(2.7)$ & $6.1(2.0)$ \\
\hline & & $\mathrm{p}=0.001$ & $26-35^{b c}$ & $5.1(2.4)$ & $4.2(1.9)$ & $5.2(2.0)$ & $6.3(1.8)$ & $7.7(1.6)$ \\
\hline & & & $36-45^{\mathrm{ab}}$ & $4.7(2.1)$ & $4.8(2.3)$ & $4.9(2.5)$ & $5.8(2.6)$ & $7.0(1.8)$ \\
\hline & & & $46-55^{a b}$ & $4.8(2.7)$ & $4.5(2.8)$ & $4.5(2.8)$ & $5.9(2.7)$ & $6.6(2.4)$ \\
\hline & & & $+55^{\mathrm{c}}$ & $5.1(1.9)$ & $4.8(2.6)$ & $6.0(3.0)$ & $6.5(2.3)$ & $7.7(1.5)$ \\
\hline & \multirow[t]{2}{*}{ Gender } & $\mathrm{F}_{4,1}=0.4$ & Male & $4.7(2.3)$ & $5.1(2.5)$ & $5.3(2.7)$ & $5.8(2.7)$ & $6.7(2.1)$ \\
\hline & & $\mathrm{p}=0.52$ & Female & $4.9(2.3)$ & $4.7(2.4)$ & $4.8(2.6)$ & $5.5(2.6)$ & $7.0(2.0)$ \\
\hline & \multirow{3}{*}{$\begin{array}{l}\text { Educational } \\
\text { level }\end{array}$} & $\mathrm{F}_{4,2}=1.3$ & Low & $5.2(2.1)$ & $5.1(2.4)$ & $4.6(2.4)$ & $4.8(2.9)$ & $6.4(1.7)$ \\
\hline & & $\mathrm{p}=0.27$ & Medium & $4.8(2.4)$ & $5.0(2.6)$ & $5.2(2.8)$ & $6.0(2.4)$ & $7.1(2.1)$ \\
\hline & & & High & $4.6(2.4)$ & $4.5(2.4)$ & $5.1(2.6)$ & $5.9(2.5)$ & $7.0(2.1)$ \\
\hline & Products & $\begin{array}{l}F_{4,643}=16.1 \\
p=0.000\end{array}$ & General mean & $4.9(2.3)^{\mathrm{a}}$ & $4.8(2.5)^{\mathrm{a}}$ & $5.0(2.6)^{\mathrm{a}}$ & $5.6(2.6)^{b}$ & $6.9(2.0)^{\mathrm{c}}$ \\
\hline \multicolumn{2}{|c|}{$\begin{array}{l}\text { Perception Products } \\
\text { of "naturality" }\end{array}$} & $\begin{array}{l}\mathrm{F}_{4,634}=9.8 \\
\mathrm{p}=0.000\end{array}$ & General mean & $5.1(2.8)^{\mathrm{a}}$ & $4.7(2.7)^{\mathrm{a}}$ & $5.1(2.5)^{\mathrm{a}}$ & $5.9(2.3)^{b}$ & $6.6(2.4)^{c}$ \\
\hline & \multirow[t]{3}{*}{ Refusal } & to taste & Whole panel \% & 4.8 & 4.1 & 14.5 & 13.0 & 17.1 \\
\hline & & & & 4.6 & 0.9 & 12.0 & 11.1 & 13.9 \\
\hline & & & $\mathrm{NC} \quad \%$ & 5.4 & 13.5 & 21.6 & 18.9 & 27.0 \\
\hline
\end{tabular}

${ }^{\mathrm{T}} \mathrm{F}$ value for the tested factor and probability associated in the analysis of variance with products and factor used 702 as independent variables

$703{ }^{2}$ Factor levels with different letters are significantly different at $\mathrm{p}<0.05$ 
Tableau 5. Positive descriptors: lexical classes and significant associations with oyster-based products, socio-demographic profiles, and oyster consumers (C) or non-consumers (NC).

\begin{tabular}{|c|c|c|c|c|}
\hline $\begin{array}{c}\text { Class } \\
\text { description }\end{array}$ & $\begin{array}{c}\% \text { of } \\
\text { classified } \\
\text { statements }\end{array}$ & Lexical universe & $\begin{array}{c}\text { Oyster- } \\
\text { based } \\
\text { product }\end{array}$ & $\begin{array}{l}\text { Socio demographic } \\
\text { profiles }\end{array}$ \\
\hline $\begin{array}{l}\text { Class } 1 \\
\text { The taste of } \\
\text { oyster and } \\
\text { sea: light, } \\
\text { choice / } \\
\text { exquisite, } \\
\text { refined }\end{array}$ & 55.0 & $\begin{array}{l}\text { Taste (25) of oyster (44), unctuous } \\
(21), \text { fresh }(17) \text {, light }(14) \text {, sea }(12) \\
\text { product }(13) \text {, choice / exquisite }(11) \text {, } \\
\text { creamy (10), taste with right balance } \\
(9) \text {, sea product }(7) \text {, iodine (5) }\end{array}$ & $\begin{array}{l}\text { Oyster } \\
\text { butter } \\
(15)\end{array}$ & $\begin{array}{l}\text { More than } 55 \text { years old (9) } \\
46-55 \text { years old ( } 7) \\
\text { Man (4) } \\
\text { Introduced to oyster } \\
\text { consumption before age of } \\
10(3) \\
\text { Raw oyster eater }(C)(3)\end{array}$ \\
\hline $\begin{array}{l}\text { Class } 2 \\
\text { Texture and } \\
\text { appearance, } \\
\text { convenience } \\
\text { issues }\end{array}$ & 37.0 & $\begin{array}{l}\text { Good (43) texture (32), small (23) } \\
\text { pieces (23) of vegetables (28), smell } \\
(28) \text { of vegetables (28), pleasant (20) } \\
\text { presentation (26), pleasant (20) } \\
\text { consistency (15), nice (19) color } \\
(18), \text { well (17) seasoned (16), easy } \\
\text { (9) to prepare (9), to spread (5) }\end{array}$ & $\begin{array}{l}\text { Cooked } \\
\text { oyster in } \\
\text { half-shell } \\
\text { (19) }\end{array}$ & $\begin{array}{l}\text { Woman }(8) \\
26-35 \text { years old (5) } \\
\text { Less than } 25 \text { years old (4) } \\
\text { Introduced to oyster } \\
\text { consumption between ages } \\
\text { of } 20 \text { and } 30 \text { (4) Students } \\
\text { (3) }\end{array}$ \\
\hline $\begin{array}{l}\text { Class } 3 \\
\text { The analogy } \\
\text { with fish- } \\
\text { based } \\
\text { products }\end{array}$ & 8.0 & $\begin{array}{l}\text { Like (72), fish (170), soup (189) or } \\
\text { potted (60) }\end{array}$ & $\begin{array}{l}\text { Soup } \\
(40)\end{array}$ & $\begin{array}{l}36-45 \text { years old (17) } \\
\text { High educational level (5) } \\
\text { Introduced to oyster } \\
\text { consumption over the age } \\
\text { of } 30(3)\end{array}$ \\
\hline
\end{tabular}

Ranking of words in lexical classes and socio demographic characteristics in decreasing order of chi-square values (chi-square value significant at $\mathrm{p}<0.05$ )

Tableau 6. Negative descriptors: lexical classes and significant associations with oysterbased products, socio-demographic profiles, and oyster consumers (C) or non consumer (NC).

\begin{tabular}{|c|c|c|c|c|}
\hline $\begin{array}{c}\text { Class } \\
\text { description }\end{array}$ & $\begin{array}{c}\% \text { of } \\
\text { classified } \\
\text { statements }\end{array}$ & Lexical universe & $\begin{array}{c}\text { Oyster- } \\
\text { based } \\
\text { product }\end{array}$ & $\begin{array}{c}\text { Socio demographic } \\
\text { profiles }\end{array}$ \\
\hline $\begin{array}{l}\text { Class } 1 \\
\text { The bizarre } \\
\text { and the } \\
\text { suspect }\end{array}$ & 37.0 & $\begin{array}{l}\text { Unpleasant (27) smell (72), } \\
\text { unappetizing (49) appearance (52) } \\
\text { and colour (32), unpleasant (19) } \\
\text { and strange (9) consistency (12), } \\
\text { strong (17), bad (8), not digested } \\
\text { (7), too dirty (5), repulsive (5) }\end{array}$ & $\begin{array}{l}\text { Soup (22) } \\
\text { Hot toast } \\
(11)\end{array}$ & $\begin{array}{l}\text { Born in land (10) } \\
\text { C consumer (6) } \\
\text { Introduced to oyster } \\
\text { consumption between the } \\
\text { ages of } 36 \text { and } 45\end{array}$ \\
\hline $\begin{array}{l}\text { Class } 2 \\
\text { The } \\
\text { incompatibility } \\
\text { with fat }\end{array}$ & 29.0 & $\begin{array}{l}\text { Fatty (73), sickly (31), sticky (28), } \\
\text { cream (27), viscous (26), doughy } \\
\text { (16), bitter (13) }\end{array}$ & $\begin{array}{l}\text { Oyster } \\
\text { butter }(31) \\
\text { Potted } \\
\text { oyster (7) }\end{array}$ & $\begin{array}{l}\text { Born in seashore }(4) \\
\text { NC consumer }(3) \\
\text { More than } 55 \text { years old } \\
(3)\end{array}$ \\
\hline $\begin{array}{l}\text { Class } 3 \\
\text { The taste of } \\
\text { oyster: } \\
\text { "tasteless or } \\
\text { too strong" }\end{array}$ & 25.0 & $\begin{array}{l}\text { Taste (79) of raw (12) oyster (105), } \\
\text { not enough (24) found again (23) } \\
\text { or too strong (5), like scallop (21) }\end{array}$ & $\begin{array}{l}\text { Cooked } \\
\text { oyster in } \\
\text { half-shell } \\
(33)\end{array}$ & $\begin{array}{l}\text { Less than } 25 \text { years old (7) } \\
\text { Student ( } 7) \\
\text { Low educational level (7) }\end{array}$ \\
\hline $\begin{array}{l}\text { Class } 4 \\
\text { The aversion } \\
\text { to oyster } \\
\text { pieces: disgust } \\
\text { towards the } \\
\text { animal itself }\end{array}$ & 9.0 & $\begin{array}{l}\text { Big (30) / too many (4) pieces } \\
\text { (145) of oyster (13), unpleasant } \\
(50), \text { not liking (42), not eating } \\
(12)\end{array}$ & $\begin{array}{l}\text { Potted } \\
\text { oyster (4) }\end{array}$ & $\begin{array}{l}\text { NC consumer }(12) \\
\text { neither raw nor cooked } \\
\text { Has never been } \\
\text { introduced to oyster } \\
\text { consumption }(6)\end{array}$ \\
\hline
\end{tabular}

